\title{
Altered circulating hormone levels, endothelial function and vascular reactivity in the testicular feminised mouse
}

\author{
Richard D Jones, Peter J Pugh ${ }^{1}$, Joanne Hall, Kevin S Channer ${ }^{1}$ and T Hugh Jones
}

Endocrine Heart and Pituitary Group, Academic Unit of Endocrinology, Division of Genomic Medicine, The University of Sheffield Medical School, Beech Hill Road, Sheffield S1O 2RX, UK and ${ }^{1}$ Department of Cardiology, Royal Hallamshire Hospital, Sheffield Teaching Hospitals NHS Trust, Glossop Road, Sheffield, S10 2JF, UK

(Correspondence should be addressed to R D Jones, Academic Unit of Endocrinology, Division of Genomic Medicine, G Floor, The Medical School, Beech Hill Road, Sheffield S1O 2RX, UK; Email: R.D.Jones@sheffield.ac.uk)

\begin{abstract}
Objective: Testicular feminised (Tfm) mice express a non-functional androgen receptor, and also have reduced levels of circulating testosterone. Recent studies support a cardio-protective role for testosterone since it elicits systemic and pulmonary vasodilatation. The aim of the present study was to determine whether androgen insensitivity and hypotestosteronaemia in the Tfm mouse are associated with abnormal vascular reactivity or hormone status.

Methods: Adult male Tfm and littermate control mice were killed and the blood collected. Femoral (diameter range $=183-508 \mu \mathrm{m})$ and pulmonary (diameter range $=320-816 \mu \mathrm{m})$ arteries were dissected and loaded in either a wire or pressure myograph, at $100 \mathrm{mmHg}$ or $17.5 \mathrm{mmHg}$ respectively. Pharmacological assessment of the vasoreactivity to potassium chloride $(\mathrm{KCl}, 80 \mathrm{mmol} / \mathrm{l})$ and either noradrenaline (NA, $1 \mathrm{nmol} / \mathrm{l}-100 \mu \mathrm{mol} / \mathrm{l}$ ) and acetylcholine (ACh, $0.1-100 \mu \mathrm{mol} / \mathrm{l})$ or testosterone $(1 \mathrm{nmol} / \mathrm{l}-100 \mu \mathrm{mol} / \mathrm{l})$ was then made.

Results: Tfm mice had reduced levels of testosterone $(1.8 \pm 0.3 \mathrm{nmol} / \mathrm{l})$ compared with controls $(9.3 \pm 2.0 \mathrm{nmol} / \mathrm{l}, \mathrm{P}<0.001)$ and elevated levels of cholesterol $(3.6+0.1 \mathrm{mmol} / \mathrm{l})$ compared with controls $(3.2+0.1 \mathrm{mmol} / \mathrm{l} . P<0.05)$. Femoral arteries from Tfm mice exhibited reduced vasoconstriction to $80 \mathrm{mmol} / \mathrm{l} \mathrm{KCl}(3.27 \pm 0.23 \mathrm{mN} / \mathrm{mm})$ compared with vessels from controls $(4.44 \pm 0.41 \mathrm{mN} / \mathrm{mm}, \quad P<0.05)$, and reduced endothelial-dependent vasodilatation to $0.1-$ $100 \mu \mathrm{mol} / \mathrm{l}$ ACh $(23.3 \pm 3.6 \%$ relaxation) compared with vessels from controls $(41.6 \pm 5.4 \%$ relaxation, $P<0.05)$. Vasoconstriction to $\mathrm{NA}(1 \mathrm{nmol} / \mathrm{l}-100 \mu \mathrm{mol} / \mathrm{l})$ and vasodilatation to testosterone were unaffected.

Conclusions: Androgen receptor deficiency and hypotestosteronaemia in the Tfm mouse reduced endothelial function and impaired voltage-operated calcium channel activity, which may pre-dispose to cardiovascular disease. Testosterone-induced vasodilatation was unaffected, demonstrating no involvement of the androgen receptor in this response.
\end{abstract}

European Journal of Endocrinology 148 111-120

\section{Introduction}

The testicular feminised (Tfm) mouse is the murine equivalent of the human condition complete androgen insensitivity syndrome (cAIS). Affected animals exhibit an X-linked, single base-pair deletion in the gene encoding the androgen receptor (1). Gene transcription consequently produces a truncated form of the receptor protein, which has a conformational change in the androgen binding site, preventing testosterone binding (2). As such these animals are rendered completely androgen insensitive and therefore phenotypically female. Because activation of the pituitary androgen receptors involved in the negative long loop feedback cannot occur, it has been hypothesised that these animals should have elevated circulating levels of luteinising hormone (LH) and therefore testosterone. However, whilst LH levels are elevated, circulating levels of testosterone are reduced in the Tfm mouse (3). This is due to a deficiency of the enzyme $17 \alpha$ hydroxylase in the Leydig cells of the testis $(3,4)$, a key constituent of the steroidogenesis pathway, the activity of which is postulated to be reduced both by the intra-abdominal location of the testes, and by the absence of androgen action in utero (3). Consequently, affected animals not only have a non-functional androgen receptor but also have a reduced circulating testosterone profile.

The role that sex hormones play in heart disease is an area that has recently received growing consideration by cardiovascular researchers. Even after correcting for differences in risk factors between the two sexes, 
men are twice as likely as women to die from coronary artery disease $(\mathrm{CAD})(5,6)$. This epidemiological evidence coupled with data suggesting that hormone replacement therapy in women is protective, and that anabolic steroid abuse can cause heart disease (reviewed in refs 7 and 8), has led to the assumption that androgens are bad for the heart. However, several studies over the last decade now suggest the opposite that testosterone is beneficial to the male cardiovascular system, and that a relative deficiency in circulating levels may lead to detrimental effects. Indeed, hypotestosteronaemia is associated with numerous risk factors for CAD including hypertension, hyperinsulinaemia, diabetes, obesity, age and adverse thrombotic profile (reviewed in ref. 9), and testosterone levels have been reported to be inversely proportional to atherosclerotic risk (10-14). Recent work by our group has demonstrated that men with significant CAD (greater than $75 \%$ stenosis on angiography) have significantly lower levels of bioavailable testosterone than a group of age- and weight-matched men with normal coronary arteries (15). This is in agreement with the findings of numerous cross-sectional case control studies which also report hypotestosteronaemia in patients with heart disease (reviewed in ref. 16). Testosterone therapy has been shown to improve myocardial ischaemia in patients with CAD, whether administered orally (17), via intra-muscular injection (18) or by transdermal patch (19). Direct intra-coronary infusion of testosterone in men with CAD induces coronary vasodilation (20) and testosterone-induced vasodilatation has also been demonstrated in animals models, encompassing a variety of vascular beds, from an assortment of species (21-27).

Clearly, evidence supports a cardio-protective role for testosterone. However, it remains unknown whether the reduction in the circulating testosterone profile seen in male patients with $\mathrm{CAD}$ is a causative factor in the development of this condition, or merely a consequence of a chronic disease state. The aim of the present study was to utilise the Tfm mouse model, to determine whether any alterations in vascular reactivity and/or vessel compliance are associated with the lack of a functional androgen receptor and reduced circulating testosterone profile, seen in this model. Such alterations may manifest as cardiovascular disease in later life, and therefore give an indication of whether hypotestosteronaemia is a cause or consequence of CAD.

\section{Materials and methods}

\section{Tfm mouse colony}

A breeding colony of Tfm mice (strain C57BL/6 J-A) was re-derived from frozen embryos obtained from the MRC mouse genome project, Harwell, Oxfordshire,

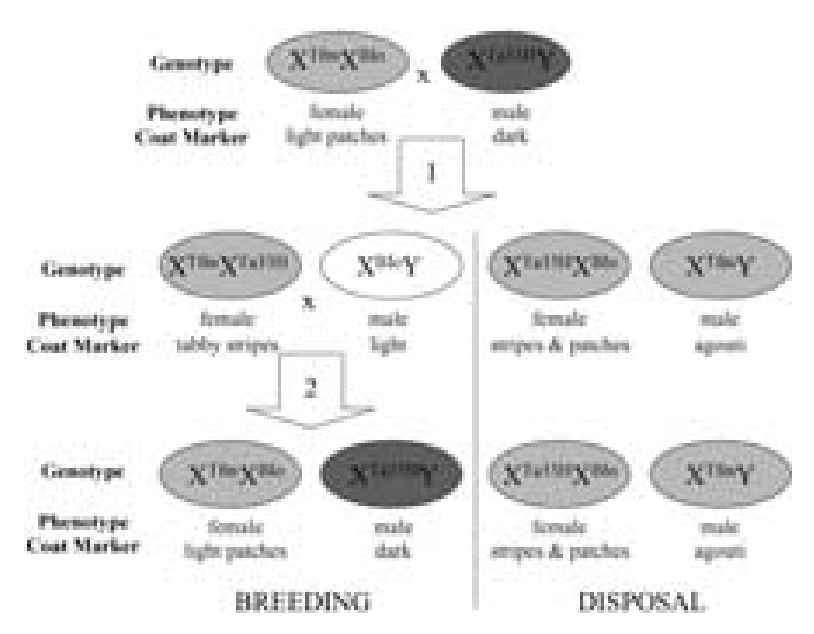

Figure 1 The two breeding schemes (1 and 2) utilised for the generation of Tfm mice ( $X^{\mathrm{Tfm}_{Y}}-$ agouti) from carrier females $\left(X^{T f m} X^{B l o}\right.$ - light patches and $X^{T f m} X^{T a 33 H}-$ tabby stripes) and non-carrier males ( $X^{\text {Ta33H }}{ }_{Y}-$ dark and $X^{B l o} Y$ - light). Non-carrier females are also depicted ( $X^{\mathrm{Ta} 33 \mathrm{H}} X^{\mathrm{Blo}}-$ stripes and patches).

UK. The genotype of the animals was determined via an inherent coat colour marker, and equal numbers of the two breeding schemes depicted in Fig. 1 were maintained in sterile barrier conditions at The University of Sheffield Field Laboratories, Western Bank, Sheffield. Non-carrier females $\left(\mathrm{X}^{\mathrm{Ta} 33 \mathrm{H}} \mathrm{X}^{\mathrm{Blo}}\right)$ and carrier females $\left(\mathrm{X}^{\mathrm{Tfm}} \mathrm{X}^{\mathrm{Ta} 33 \mathrm{H}}\right.$ or $\left.\mathrm{X}^{\mathrm{Tfm}} \mathrm{X}^{\mathrm{Blo}}\right)$ not required for breeding were killed via a UK Home Office-approved Schedule 1 method, once weaned. Male offspring $\left(\mathrm{X}^{\mathrm{Ta} 33 \mathrm{H}} \mathrm{Y}\right.$ or $\mathrm{X}^{\mathrm{Blo}} \mathrm{Y}$ ) that were not required for re-stocking the breeding colony, and Tfm offspring $\left(\mathrm{X}^{\mathrm{Tfm}} \mathrm{Y}\right)$ were transferred at 6 weeks of age to the local field laboratories based at the Royal Hallamshire Hospital, Sheffield.

\section{Assessment of plasma hormone levels}

Tfm mice $\left(\mathrm{X}^{\mathrm{Tfm}} \mathrm{Y}\right)$ and male littermate controls $\left(\mathrm{X}^{\mathrm{Ta} 33 \mathrm{H}} \mathrm{Y}\right.$ and $\left.\mathrm{X}^{\mathrm{Blo}} \mathrm{Y}\right)$ of a similar age as those used in subsequent experiments $(\mathrm{Tfm}, n=46$, mean age $=$ $75 \pm 1$ days; controls, $n=40$, mean age $=74 \pm 1$ days) or between 3 and 8 months old (Tfm, $n=42$, mean age $=140 \pm 7$ days; controls $n=51$, mean age $=151 \pm 7$ days) were killed via cervical dislocation as approved by the UK Home Office. A mid-line sternotomy was performed, the rib-cage opened, and the blood removed from the chest cavity following severance of the thoracic aorta, using a sterile $1 \mathrm{ml}$ pipette. The blood was then transferred to a $1.5 \mathrm{ml}$ Eppendorf tube, placed on ice and taken immediately to the research laboratory. The blood was spun in a centrifuge for $10 \mathrm{~min}$ at 3000 r.p.m., the plasma collected and transferred to a fresh $1.5 \mathrm{ml}$ Eppendorf tube and stored at $-20^{\circ} \mathrm{C}$ for later analysis. Total testosterone levels were measured using commercially available ELISA kits (Immuno Diagnostic Systems Ltd, Boldon, Tyne and Wear, UK). Total cholesterol, progesterone 
and cortisol levels were analysed by the Department of Clinical Chemistry, Royal Hallamshire Hospital, Sheffield, using in-house ELISA. All ELISA analysis was undertaken using mouse antibodies.

\section{Assessment of vascular reactivity of testosterone by wire myography}

Femoral arteries $(n=48$, mean internal diameter $=$ $322 \pm 9 \mu \mathrm{m})$ from $\mathrm{Tfm}(n=8$, mean age $=72 \pm 2$ days) and littermate control mice $(n=8$, mean age $=$ $72 \pm 2$ days), and pulmonary arteries $(n=46$, mean internal diameter $=512 \pm 14 \mu \mathrm{m})$ from $\mathrm{Tfm}(n=7$, mean age $=72 \pm 1$ days) and littermate control mice ( $n=7$, mean age $=74 \pm 1$ days $)$, were used in this series of experiments. Between three and four femoral and pulmonary vessels were dissected initially from each animal, although four pulmonary arteries and three femoral arteries were later discarded due to either having a damaged endothelial or smooth muscle cell layer (see below).

The technique of wire myography is commonly utilised for vascular reactivity studies and has been described in detail elsewhere (28). Briefly, vessels were mounted on two $40 \mu \mathrm{m}$ stainless steel wires in the jaws of an automated wire myograph (Cambustion Ltd, Cambridge, Cambridgshire, UK), the myograph bath filled with physiological saline solution (PSS) heated to $37^{\circ} \mathrm{C}$ and bubbled with $95 \% \mathrm{O}_{2} / 5 \% \mathrm{CO}_{2}$ to maintain a physiological $\mathrm{pH}$ of 7.4 . Length-tension characteristics were obtained via the myograph software (Cambustion Ltd) and on the basis of these, femoral arteries were loaded to a tension equivalent to an in vivo pressure of $100 \mathrm{mmHg}$, and pulmonary arteries were loaded to a tension equivalent to an in vivo pressure of $17.5 \mathrm{mmHg}$. The vessels were then left to equilibrate under these conditions for $1 \mathrm{~h}$, after which they were exposed three times to $80 \mathrm{mmol} / \mathrm{l}$ potassium chloride $(\mathrm{KCl})$, to ensure that the vessels were viable and that responses to applied agonists were reproducible. Vessels were then washed and exposed to noradrenaline (NA; $10 \mu \mathrm{mol} / \mathrm{l})$, and once a maximal contraction had been produced, acetylcholine (ACh; $10 \mu \mathrm{mol} / \mathrm{l}$ ) was added to confirm the presence of an intact endothelial cell layer. The vessels were then washed, re-exposed to NA $(10 \mu \mathrm{mol} / \mathrm{l})$ and once a maximal contraction had been achieved, cumulative additions of either testosterone $(0.1-100 \mu \mathrm{mol} / \mathrm{l})$ or an equivalent volume of ethanol vehicle were made, and changes in tension recorded. The final bath concentration of ethanol was $<0.3 \%$.

\section{Assessment of vascular reactivity of testosterone by pressure myography}

Femoral arteries $(n=24$, mean external diameter $=$ $426 \pm 11 \mu \mathrm{m})$ were dissected carefully from Tfm $(n=$ 12 , mean age $=74 \pm 2$ days) and littermate control mice $(n=12$, mean age $=78 \pm 2$ days) (one vessel per animal), for study by pressure myography. Again, the technique of pressure myography has been has been described in detail elsewhere (29). Briefly, vessels were mounted on two glass pipettes in a pressure myograph system (Living Systems, Burlington VT, USA), and held in place with three strands of synthetic thread at either end. The myograph bath was filled with PSS heated to $37^{\circ} \mathrm{C}$ and bubbled with $95 \%$ $\mathrm{O}_{2} / 5 \% \mathrm{CO}_{2}$ to maintain a physiological $\mathrm{pH}$ of 7.4 . The end of the pipette distal to the vessel was sealed, and PSS pumped slowly into the vessel using a pressure servo, via capillary tubing attached to the proximal end of the vessel. An in-line pressure transducer was located in the circuit proximal to the vessel to enable measurement of the pressure within the system. The vessel was then slowly pressurised in $10 \mathrm{mmHg}$ gradations to a resting pressure of $100 \mathrm{mmHg}$. A feedback loop to the pressure servo ensured that the vessel was held at this constant resting pressure. External diameter was monitored continuously using a Video Dimension Analyser (Living Systems). Signals from the pressure transducers and Video Dimension Analyser were digitised and stored on a computer loaded with WINDAQ data acquisition system software (Dataq Instruments, Akron, OH, USA). The vessels were left to equilibrate under these conditions for $1 \mathrm{~h}$, and were then exposed three times to $80 \mathrm{mmol} / \mathrm{l} \mathrm{KCl}$, to ensure that the vessels were viable and that responses to applied agonists were reproducible. Vessels were then washed and exposed to NA $(1 \mu \mathrm{mol} / \mathrm{l})$, and once a maximal contraction had been produced, ACh $(10 \mu \mathrm{mol} / \mathrm{l})$ was added to confirm the presence of an intact endothelial cell layer. The vessels were then washed, re-exposed to NA $(1 \mu \mathrm{mol} / \mathrm{l})$ and once a maximal contraction had been produced, cumulative additions of either testosterone $(1 \mathrm{nmol} / \mathrm{l}-100 \mu \mathrm{mol} / \mathrm{l})$ or an equivalent volume of ethanol vehicle were made, and changes in external vessel diameter recorded. The final bath concentration of ethanol was $<0.5 \%$.

\section{Assessment of changes in agonist-induced responses and endothelial function}

Femoral arteries $(n=40$, mean internal diameter $=$ $332 \pm 9 \mu \mathrm{m})$ from $\mathrm{Tfm}(n=7$, mean age $=71 \pm 2$ days) and littermate control mice $(n=7$, mean age $=$ $72 \pm 2$ days) were used in this series of experiments. Three femoral arteries were initially dissected from each animal, although two were later discarded due to having a damaged smooth muscle cell layer. Vessels were mounted on two $40 \mu \mathrm{m}$ stainless steel wires in the jaws of an automated wire myograph (Cambustion Ltd) as described above. After the $1 \mathrm{~h}$ equilibration period the vessels were exposed three times to $80 \mathrm{mmol} / \mathrm{l} \mathrm{KCl}$, to ensure that the vessels were viable and that responses to applied agonists were reproducible. 
Vessels were then washed and exposed to NA ( $1 \mathrm{nmol} / \mathrm{l}-$ $100 \mu \mathrm{mol} / \mathrm{l}$ ), and once a maximal contraction had been produced, ACh $(0.1-100 \mu \mathrm{mol} / \mathrm{l})$ was added and changes in tension recorded.

\section{Assessment of changes in vascular compliance}

Femoral arteries $(n=37$, mean internal diameter $=$ $326 \pm 10 \mu \mathrm{m})$ were dissected carefully from Tfm $(n=$ 7 , mean age $=71 \pm 2$ days) and littermate control mice $(n=7$, mean age $=72 \pm 2$ days $)$ for the assessment of vessel compliance. Three vessels were dissected per animal, but five vessels were not included in the analysis (four from Tfm and one from control animals) on this basis that they had received excessive handling, and in the absence of pharmacological evidence we could not be sure that damage to the smooth muscle cell layer had not occurred.

Vessels were mounted on two $40 \mu \mathrm{m}$ stainless steel wires in the jaws of an automated wire myograph (Cambustion Ltd) as described above. Diameter-tension curves were then obtained for each vessel, as previously described (30). Starting at a diameter that yielded no tension on the vessel, the myograph jaws were separated at a rate of $50 \mu \mathrm{m} / \mathrm{s}$ until the force exerted on each vessel reached a maximum tension of $25 \mathrm{mN}$. The myograph jaws were then returned to their original position at the same rate, until zero tension was obtained. The two diameter tension curves were stored within the myograph software (Cambustion Ltd) and the mean of the two curves plotted. The change in diameter divided by the change in tension $(\Delta x / \Delta y)$ was then calculated as a measure of dynamic vessel compliance $(\mu \mathrm{m} / \mathrm{mN})$. This was measured over the diameter range $\pm 50 \mu \mathrm{m}$ of the diameter at which each vessel possessed a tension equivalent to $100 \mathrm{mmHg}$. This diameter range was selected as it was representative of the in vivo variability in vessel diameter.

\section{Solutions and drugs}

PSS consisted of $120 \mathrm{mmol} / \mathrm{l} \mathrm{NaCl}, 4.7 \mathrm{mmol} / \mathrm{l} \mathrm{KCl}$, $1.17 \mathrm{mmol} / \mathrm{l} \mathrm{MgSO}_{4}, 25 \mathrm{mmol} / \mathrm{l} \mathrm{NaHCO}_{3}, 1.18 \mathrm{mmol} / \mathrm{l}$ $\mathrm{KH}_{2} \mathrm{PO}_{4}, 5.5 \mathrm{mmol} / \mathrm{l}$ glucose, $2.5 \mathrm{mmol} / \mathrm{l} \mathrm{CaCl} 2$ and $26.9 \mu \mathrm{mol} / \mathrm{l}$ EDTA dissolved in distilled water. All PSS reagents were obtained from Sigma UK Ltd. NA, ACh and $\mathrm{KCl}$ were all obtained from Sigma UK Ltd and dissolved in distilled water to the required concentration. Testosterone was also obtained from Sigma UK Ltd but was dissolved in ethanol.

\section{Statistical analysis}

Results are expressed as means \pm S.E.M. Statistical analysis was made by Student's paired or unpaired $t$-test for parametric data, and by Mann-Whitney U test for non-parametric data. In all cases $P<0.05$ was considered to be statistically significant.

\section{Results}

\section{Plasma hormone levels}

The hormone levels from the Tfm $\left(\mathrm{X}^{\mathrm{Tfm}} \mathrm{Y}\right)$ and male littermate control mice $\left(\mathrm{X}^{\mathrm{Ta} 33 \mathrm{H}} \mathrm{Y}\right.$ and $\left.\mathrm{X}^{\mathrm{Blo}} \mathrm{Y}\right)$ are shown in Table 1 . The intra- and interassay coefficients of variance were $<5 \%$ in all cases. Because the hormone measurement assay consumed a significant volume of blood from each sample, in some cases insufficient sample remained for some of the subsequent assays. As such, from the 179 plasma samples collected, 179 values of total testosterone, 117 values of total cholesterol, 58 values of total progesterone and 48 values of total cortisol were obtained.

Table 1 Mean (S.E.M.) plasma hormone levels from adult Tfm and littermate control mice.

\begin{tabular}{lllll}
\hline & \multicolumn{1}{c}{$\mathrm{X}^{\mathrm{Tfm} Y}$} & $\mathrm{XY}$ & $\mathrm{X}^{\mathrm{Tfm} Y}$ & $\mathrm{XY}$ \\
\hline Age (days) & $75(1)$ & $74(1)$ & $140(7)$ & $151(7)$ \\
$n$ & 46 & 40 & 42 & 51 \\
Total testosterone (nM) & $1.8(0.3)$ & $9.3(2.0)^{\dagger}$ & $1.4(0.1)$ & $16.5(2.9)^{\dagger}$ \\
$n$ & 46 & 40 & 42 & 51 \\
Total cholesterol (mM) & $3.6(0.1)$ & $3.2(0.1)^{*}$ & $3.6(0.3)$ & $2.8(0.1)^{\star *}$ \\
$n$ & 39 & 35 & 22 & 21 \\
Total progesterone (nM) & $4.0(0.4)$ & $4.9(0.6)$ & $5.9(0.5)$ & $4.7(0.5)$ \\
$n$ & 7 & 26 & 8 & 17 \\
Total cortisol (nM) & $28.1(0.5)$ & $30.8(2.2)$ & $28.0(1.0)$ & $40.5(4.5)$ \\
$n$ & 21 & 23 & 2 & 2 \\
\hline
\end{tabular}

${ }^{\star} P<0.05,{ }^{* *} P<0.01,{ }^{\dagger} P<0.001$ compared with age-matched Tfm mice via Student's unpaired $t$-test. 
Table 2 Vessel characteristics and baseline vasoreactivity to $\mathrm{KCl}, \mathrm{NA}$ and ACh for the pulmonary and femoral arteries isolated from $\mathrm{Tfm}$ and littermate control mice, utilised for the study of the vascular reactivity of testosterone. Results are expressed as means \pm S.E.M.

\begin{tabular}{|c|c|c|c|c|c|c|}
\hline & $\begin{array}{c}\mathrm{XY} \\
\text { Pulmonary } \\
\text { arteries }\end{array}$ & $\begin{array}{c}\text { Tfm } \\
\text { Pulmonary } \\
\text { arteries }\end{array}$ & $\begin{array}{c}\mathrm{XY} \\
\text { Femoral } \\
\text { arteries } \\
\text { (wire } \\
\text { myography) }\end{array}$ & $\begin{array}{c}\text { Tfm } \\
\text { Femoral } \\
\text { arteries } \\
\text { (wire } \\
\text { myography) }\end{array}$ & $\begin{array}{l}\text { XY } \\
\text { Femoral } \\
\text { arteries } \\
\text { (pressure } \\
\text { studies) }\end{array}$ & $\begin{array}{l}\text { Tfm } \\
\text { Femoral } \\
\text { arteries } \\
\text { (pressure } \\
\text { studies) }\end{array}$ \\
\hline$n$ & 23 & 23 & 25 & 23 & 12 & 12 \\
\hline Diameter $(\mu \mathrm{m})$ & $525 \pm 20$ & $498 \pm 21$ & $315 \pm 13$ & $330 \pm 13$ & $420 \pm 17$ & $430 \pm 16$ \\
\hline Contraction to $80 \mathrm{mM} \mathrm{KCl}$ & $\begin{array}{l}1.59 \pm 0.13 \\
\mathrm{mN} / \mathrm{mm}\end{array}$ & $\begin{array}{l}1.65 \pm 0.20 \\
\mathrm{mN} / \mathrm{mm}\end{array}$ & $\begin{array}{l}4.67 \pm 0.40 \\
\mathrm{mN} / \mathrm{mm}\end{array}$ & $\begin{array}{l}3.37 \pm 0.24^{\star *} \\
\mathrm{mN} / \mathrm{mm}\end{array}$ & $\begin{array}{c}-173 \pm 14 \\
\Delta \mu \mathrm{m}\end{array}$ & $\begin{array}{c}-128 \pm 11 \\
\Delta \mu \mathrm{m}\end{array}$ \\
\hline Contraction to $1 \mu \mathrm{M}$ NA & - & - & - & - & $\begin{array}{c}-152 \pm 14 \\
\Delta \mu \mathrm{m}\end{array}$ & $\begin{array}{c}-176 \pm 14 \\
\Delta \mu \mathrm{m}\end{array}$ \\
\hline Contraction to $10 \mu \mathrm{M} N A$ & $\begin{array}{l}0.97 \pm 0.10 \\
\mathrm{mN} / \mathrm{mm}\end{array}$ & $\begin{array}{l}1.13 \pm 0.07 \\
\mathrm{mN} / \mathrm{mm}\end{array}$ & $\begin{array}{l}4.67 \pm 0.51 \\
\mathrm{mN} / \mathrm{mm}\end{array}$ & $\begin{array}{c}4.16 \pm 0.34 \\
\mathrm{mN} / \mathrm{mm}\end{array}$ & - & - \\
\hline Dilatation to $10 \mu \mathrm{M} \mathrm{ACh}$ & $\begin{array}{c}-0.30 \pm 0.06 \\
\mathrm{mN} / \mathrm{mm}\end{array}$ & $\begin{array}{c}-0.25 \pm 0.03 \\
\mathrm{mN} / \mathrm{mm}\end{array}$ & $\begin{array}{c}-2.14 \pm 0.39 \\
\mathrm{mN} / \mathrm{mm}\end{array}$ & $\begin{array}{c}-1.08 \pm 0.23^{*} \\
\mathrm{mN} / \mathrm{mm}\end{array}$ & $\begin{array}{l}50 \pm 11 \\
\Delta \mu \mathrm{m}\end{array}$ & $\begin{array}{l}53 \pm 13 \\
\Delta \mu \mathrm{m}\end{array}$ \\
\hline
\end{tabular}

${ }^{*} P<0.05$ and ${ }^{* *} P<0.01$ compared with similar vessels from control animals via Student's unpaired $t$-test.

Tfm mice had a total testosterone level significantly lower than the littermate controls, and also exhibited an elevated level of total cholesterol. This was consistent whether analysis was made in animals of experimental age or animals of mature adult age. No significant alterations were seen in the circulating plasma levels of progesterone or cortisol between $\mathrm{Tfm}$ and littermate controls.

\section{Vascular reactivity of testosterone - wire myography}

The vessel characteristics and vasoreactivity of the pulmonary arteries and femoral arteries utilised in this series of experiments are shown in Table 2.

The diameter and baseline responsiveness to $\mathrm{KCl}$ $(80 \mathrm{mmol} / \mathrm{l})$, NA $(10 \mu \mathrm{mol} / \mathrm{l})$ and ACh $(10 \mu \mathrm{mol} / \mathrm{l})$ of the pulmonary arteries from Tfm and littermate control mice were similar in all cases (Table 2). Vasodilatation to testosterone was also similar in pulmonary arteries from Tfm and littermate control mice (Fig. 2A). Significant dilatation to testosterone (compared with ethanol vehicle) was seen at 10,30 and $100 \mu \mathrm{mol} / \mathrm{l}$, with approximately $100 \%$ reversal of the pre-contractile tone induced by NA $(10 \mu \mathrm{mol} / \mathrm{l})$ occurring at $100 \mu \mathrm{mol} / \mathrm{l}$ (Fig. 2A). Significantly greater dilatation to testosterone was seen at a concentration of $30 \mu \mathrm{mol} / \mathrm{l}$ in vessels from littermate control animals (Fig. 2A).

The diameter and baseline responsiveness to NA $(10 \mu \mathrm{mol} / \mathrm{l})$ was also similar in femoral arteries from $\mathrm{Tfm}$ and littermate control mice (Table 2). However the contraction induced by $\mathrm{KCl}(80 \mathrm{mmol} / \mathrm{l})$ and the dilatation to ACh $(10 \mu \mathrm{mol} / \mathrm{l})$ was reduced in femoral arteries from Tfm mice (Table 2). As with the pulmonary arteries, the vasodilatory efficacy of testosterone was not significantly altered in femoral arteries from Tfm mice (Fig. 2B), although the potency of testosterone was enhanced compared with pulmonary arteries. Significant dilatation to testosterone (compared with ethanol vehicle) was seen at 1, 3, 10, 30 and $100 \mu \mathrm{mol} / \mathrm{l}$ in femoral arteries from littermate controls, and at 3,10, 30 and $100 \mu \mathrm{mol} / \mathrm{l}$ in femoral arteries from Tfm animals (Fig. 2B). Again, approximately $100 \%$ reversal of the pre-contractile tone induced by NA $(10 \mu \mathrm{mol} / \mathrm{l})$ occurred at $100 \mu \mathrm{mol} / \mathrm{l}$ (Fig. 2B). Responses to testosterone in femoral arteries from $\mathrm{Tfm}$ and littermate control mice did not differ significantly at any concentration tested.

\section{Vascular reactivity of testosterone - pressure myography}

The diameter and baseline responsiveness to $\mathrm{KCl}$ $(80 \mathrm{mmol} / \mathrm{l})$, NA $(1 \mu \mathrm{mol} / \mathrm{l})$ and ACh $(10 \mu \mathrm{mol} / \mathrm{l})$ were similar in femoral arteries from Tfm and littermate control mice utilised in this series of experiments (Table 2). As with the femoral arteries studied by wire myography, the vasodilatory efficacy of testosterone was not significantly altered in femoral arteries from Tfm mice (Fig. 2C). Significant dilatation to testosterone (compared with ethanol vehicle) was seen at 3, 10, 30 and $100 \mu \mathrm{mol} / \mathrm{l}$ in femoral arteries from both $\mathrm{Tfm}$ and littermate control mice (Fig. 2C). Only approximately $70 \%$ reversal of the pre-contractile tone induced by NA $(1 \mu \mathrm{mol} / \mathrm{l})$ was seen at $100 \mu \mathrm{mol} / \mathrm{l}$ testosterone (Fig. 2C). Responses to testosterone in femoral arteries from Tfm and littermate control mice did not differ significantly at any concentration tested.

\section{Vascular reactivity of $\mathrm{NA}$ and $\mathrm{ACh}$}

The femoral arteries harvested from Tfm and littermate control mice were of similar diameter: $334 \pm 14 \mu \mathrm{m}$ 

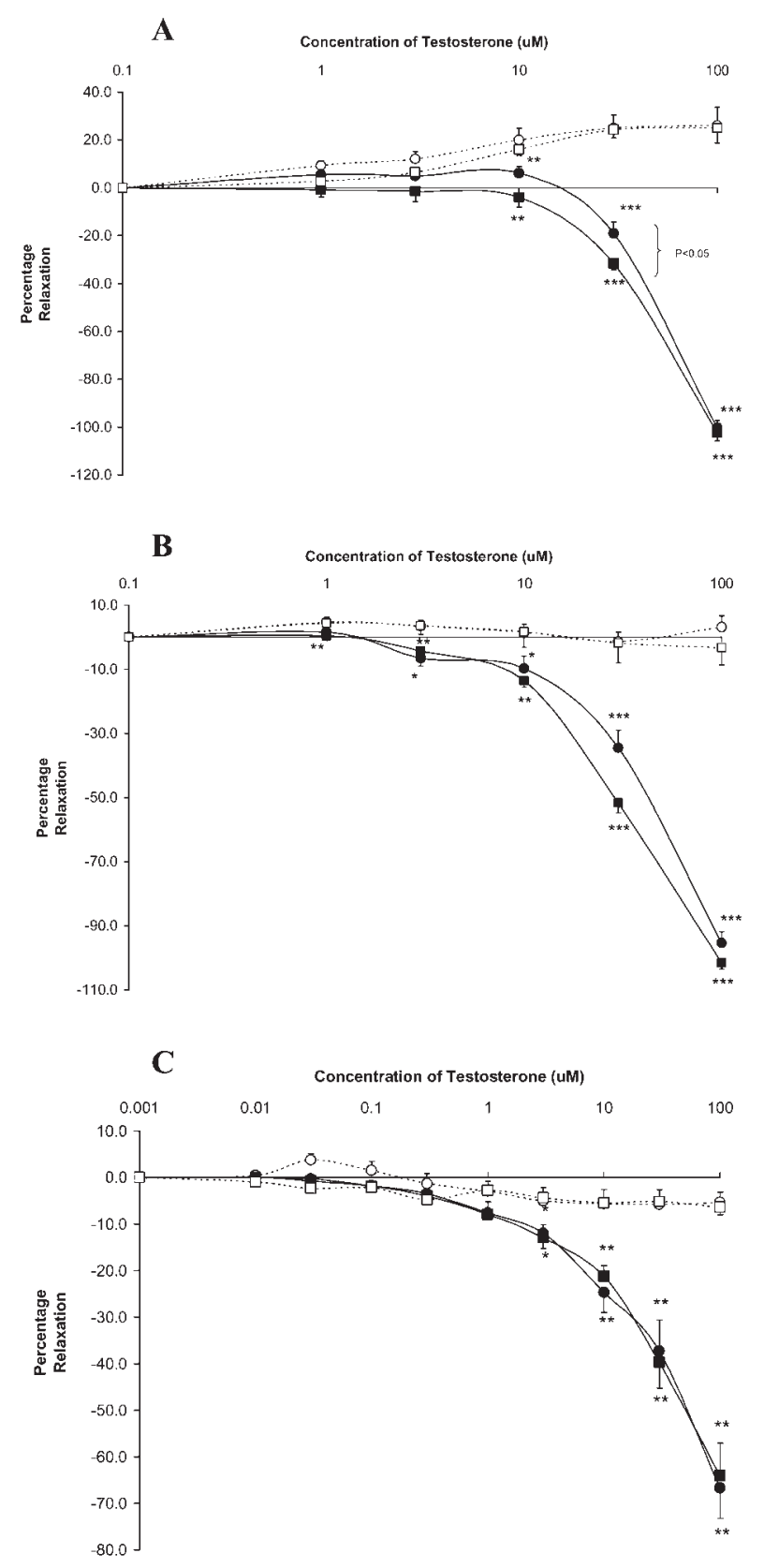

Figure 2 The concentration-response curve to testosterone compared with ethanol vehicle in isolated pulmonary arteries studied via wire myography $(A)$, in isolated femoral arteries studied via wire myography (B) and in isolated femoral arteries studied via pressure myography (C). •, Response to testosterone in vessels harvested from Tfm mice. $\mathbf{\square}$, Response to testosterone in vessels harvested from control mice. $\bigcirc$, Response to ethanol vehicle in vessels harvested from Tfm mice. $\square$,

Response to ethanol vehicle in vessels harvested from control mice. ${ }^{\star} P<0.05,{ }^{\star \star} P<0.01$ and ${ }^{* \star \star} P<0.001$ compared with the respective vehicle-exposed control vessels via Mann-Whitney $U$ test. Results are expressed as means \pm S.E.M. $(n=19)$ and $312 \pm 13 \mu \mathrm{m}(n=21)$ respectively, but their vasoreactivity was significantly altered. Mean contraction to $\mathrm{KCl}(80 \mathrm{mmol} / \mathrm{l})$ was reduced in vessels from $\mathrm{Tfm}$ mice: $3.27 \pm 0.23 \mathrm{mN} / \mathrm{mm}$ compared with $4.44 \pm 0.41 \mathrm{mN} / \mathrm{mm}$ in vessels from littermate controls $(P<0.05$, Student's unpaired t-test). Endothelialdependent vasodilatation to ACh $(0.1-100 \mu \mathrm{mol} / \mathrm{l})$ was also significantly reduced in vessels from $\mathrm{Tfm}$ mice: $E_{\max }=23.3 \pm 3.6 \%$ relaxation compared with $41.6 \pm 5.4 \%$ relaxation in vessels from littermate control mice $(P<0.05$, Student's unpaired $t$-test) (Fig. 3). Significantly lower vasodilatation to ACh was seen at concentrations of $0.1,0.3,1$ and $30 \mu \mathrm{mol} / \mathrm{l}$ (Fig. $3)$. The contractile response to $\mathrm{NA}$ ( $1 \mathrm{nmol} / \mathrm{l}-$ $100 \mu \mathrm{mol} / \mathrm{l}$ ) was similar in vessels from Tfm and littermate control mice (Fig. 4).

\section{Vascular compliance}

The femoral arteries harvested from Tfm and littermate control mice were of similar diameter: $342 \pm 14 \mu \mathrm{m}$

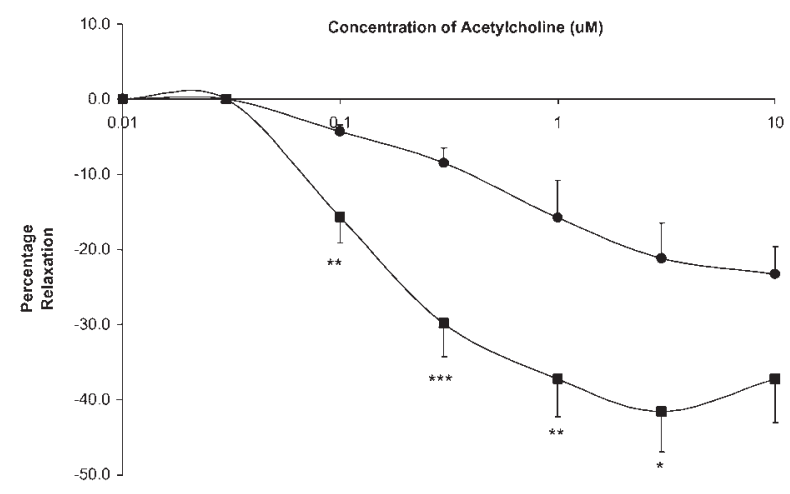

Figure 3 The concentration-response curve to ACh in isolated femoral arteries harvested from $\operatorname{Tfm}(\bullet)$ and littermate control mice $(\square)$. ${ }^{*} P<0.05,{ }^{* \star} P<0.01$ and ${ }^{* * *} P<0.001$ via Student's unpaired $t$-test. Results are expressed as means \pm S.E.M.

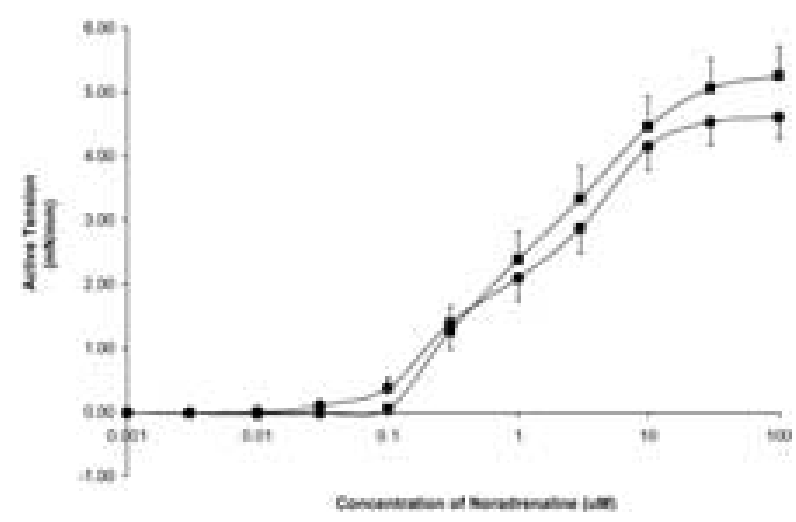

Figure 4 The concentration-response curve to NA in isolated femoral arteries harvested from $\operatorname{Tfm}(\bullet)$ and littermate control mice (ם). Results are expressed as means \pm S.E.M. 
$(n=17)$ and $312 \pm 13 \mu \mathrm{m}(n=20)$ respectively. The compliance of the vessels from the Tfm mice was lower than the compliance of the vessels from littermate control mice: $5.09 \pm 0.36 \mu \mathrm{m} / \mathrm{mN}$ and $5.98 \pm 0.37 \mu \mathrm{m} / \mathrm{mN}$ respectively, although this failed to reach statistical significance $(P=0.1$, Student's unpaired $t$-test).

\section{Discussion}

The main findings of the present study were that androgen receptor deficient Tfm mice had significantly altered circulating plasma levels of both testosterone and cholesterol, and that these alterations were associated with impaired endothelial-dependent vasodilatation and reduced vascular reactivity to $\mathrm{KCl}$. The vasodilatory action of testosterone was not altered significantly.

Tfm mice had an approximately tenfold lower circulating level of total testosterone compared with littermate control animals, a deficiency that was maintained across all the age ranges of animals tested $(8$ weeks to 8 months old). The fact that Tfm mice have a reduced circulating testosterone profile has previously been reported (3) and is attributed to a deficiency of the enzyme $17 \alpha$ hydroxylase $(3,4)$, which is a key constituent of the steroidogenesis pathway whereby sex steroids are synthesised from cholesterol in the gonads. The effect of this enzyme deficiency on the circulating levels of other steroid hormones has not previously been reported. In the present study we have demonstrated that $\mathrm{Tfm}$ mice also have an elevated level of circulating plasma cholesterol compared with littermate controls (Table 1), and although this rise was modest, it reached statistical significance in all groups tested. Hence the present study has demonstrated an elevation in the levels of the initial substrate of the steroidogenesis pathway, and a reduction in the levels of the end product, consistent with $17 \alpha$ hydroxylase deficiency. However the levels of progesterone, another substrate for $17 \alpha$ hydroxylase, were not significantly altered (Table 1), although this may be a consequence of the relatively low numbers of samples analysed from the Tfm group (15 compared with 43) (Table 1). The levels of cortisol, another product downstream of $17 \alpha$ hydroxylase, were reduced in Tfm animals (Table 1), but this also did not reach statistical significance for the number of samples analysed.

We then went on to determine whether these changes in the circulating hormone profile had any effect upon vascular reactivity, initially responsiveness to testosterone. Previous work has demonstrated that testosterone elicits vasodilatation via a mechanism that is postulated to be independent of the nuclear androgen receptor due to its rapid onset and insensitivity to the androgen receptor blocker flutamide $(21,25$, 26). Furthermore, the vasodilatory response is preserved when testosterone is covalently bound to bovine serum albumin, which prevents the entry of testosterone into the smooth muscle cell, thus preventing interaction with the nuclear androgen receptor (31). Whilst this strongly suggests that testosterone does not elicit vasodilation via interaction with this nuclear androgen receptor, it does not rule out activation of a membranebound androgen receptor, as has been proposed in other cells $(32-34)$. Indeed, we have been able to demonstrate the presence of a membranous testosterone binding site in cultured arterial smooth muscle cells (35) and this may be a receptor governing testosterone-induced vasodilatation. Preliminary experiments demonstrated that the vasodilatory activity of testosterone was unaffected in isolated thoracic aortae from Tfm mice (36). In the present study we wanted to determine whether the vasodilatory action of testosterone in other vascular beds was also independent of this genomic signalling pathway, and if the potency of testosterone could be enhanced using a more physiological technique. Consequently, we studied the vasodilatory action of testosterone in isolated pulmonary and femoral arteries using both wire and pressure myography. Due to the branched nature of the pulmonary vascular bed, pulmonary arteries could not be pressurised in this system, and consequently these experiments were restricted to femoral arteries.

Testosterone-induced vasodilatation in both these vascular beds and preparations was unaffected by the absence of a functional androgen receptor, and by the observed testosterone deficiency. These data further substantiate the hypothesis that testosterone-induced vasodilatation does not involve activation of the androgen receptor, and also suggests that the membranous testosterone binding site previously identified by our group and hypothesised to mediate the vasodilatory activity of testosterone, is not an androgen receptor. Furthermore, because the vasodilatory capacity of testosterone is not potentiated in vessels from testosterone-deficient Tfm mice, it would also suggest that this binding site may not be a testosterone-specific receptor, since upregulation of the 'receptor' has clearly not occurred. This adds further weight to the argument that testosterone may be capable of regulating vascular tone via interaction with an ion channel in the smooth muscle cell membrane, as has been suggested previously by ourselves and others $(21,23-27)$.

The concentration at which testosterone produced vasodilatation remained in the pharmacological, rather than physiological, range, despite using the more physiological technique of pressure myography (Fig. 2B,C). However, such a difference between in vitro experimentation and the in vivo situation is common. For example, cromakalin, a potassium channel opener, reduces systolic arterial pressure and systemic vascular resistance in vivo at concentrations of $2-3 \times$ $10^{-8} \mathrm{~mol} / \mathrm{l}$. In vitro, however, vasodilatory effects are only seen at $10^{-6}-10^{-5} \mathrm{~mol} / \mathrm{l}$, a similar discrepancy 
to the present situation (circulating total testosterone levels being approximately $10^{-8} \mathrm{~mol} / \mathrm{l}-$ Table 1 ). The necessity of a high concentration of testosterone to induce vasodilatation raises the issue of whether cross-reactivity at oestrogen receptors or conversion to $17 \beta$ oestradiol via the enzyme aromatase occurs. However this is unlikely for a number of reasons. Firstly, a number of studies have directly investigated the involvement of oestrogens in the vasodilation induced by testosterone. Chou et al. (22) reported that the oestrogen receptor blocker ICI-182780 had no inhibitory effect upon testosterone-mediated dilatation of canine coronary arteries, and the studies of Yue et al. (21) and Tep-areenan et al. (26) both demonstrate that the vasodilatory efficacy of testosterone is not attenuated in the presence of the aromatase inhibitor aminoglutethimide. Furthermore, previous work by our group has demonstrated that the vasodilatory efficacy of oestradiol- $17 \beta$ is significantly lower than testosterone in the pulmonary vasculature (37). Consequently, aromatase-mediated conversion of testosterone into oestradiol- $17 \beta$ is unlikely to be involved in this vasodilatory response. The high concentration of testosterone required to induce vascular relaxation is mirrored by other non-genomic steroid signalling pathways (38-40), and such responses may well represent efficacy at a low affinity receptor - a number of which have recently been identified (41).

From these initial experiments looking at the vasodilatory capability of testosterone, an apparent difference in vascular reactivity to $\mathrm{KCl}$ and $\mathrm{ACh}$ in vessels harvested from Tfm and control vessels was observed. In the femoral arteries studied via wire myography, the initial contractions to $\mathrm{KCl}$, which were utilised to ensure the viability of each vessel following dissection and mounting, were significantly reduced in the vessels obtained from Tfm mice. Similarly, the endothelialdependent dilatation to ACh following preconstriction with NA was also reduced in these vessels. Because of the reduction in response to $\mathrm{ACh}$, we decided to repeat these experiments over the whole concentrationresponse range of $\mathrm{ACh}$, and also NA, to determine whether there were any significant alterations in endothelial function and agonist-induced contraction. We also wanted to study the vessel compliance to determine whether there was any evidence of vascular remodelling.

Significant attenuation of the response to ACh (0.1$100 \mu \mathrm{mol} / \mathrm{l}$ ) was observed in the femoral arteries obtained from Tfm mice over all concentration ranges (Fig. 3). No significant alterations in the response to NA were observed (Fig. 4) although, as in the previous experiments, the initial exposures to $\mathrm{KCl}$ utilised to confirm vessel viability were significantly reduced. No significant alterations in femoral artery compliance were observed, although this was lower in the Tfm group. These findings contradict a recent study utilising the Tfm rat model that demonstrated a reduction in vasoconstriction to NA and no change in vasoconstriction to $\mathrm{KCl}$ in thoracic aortae harvested from Tfm rats (42). However, this group also demonstrated that contraction to NA was dependent upon both sex and NO release (42), and the authors conclude that their results demonstrate that NO signalling is androgen receptor dependent, which is in agreement with the findings of the present study.

The observation that reduced vasodilatation to ACh occurred in the vessels harvested from Tfm mice demonstrates that endothelial function is impaired in these animals. In addition, the finding that vasoconstriction to $\mathrm{KCl}$ was also attenuated suggests that calcium channel function is also reduced in the Tfm mouse. NA and $\mathrm{KCl}$ both elicit smooth muscle contraction by triggering extracellular calcium entry following calcium channel activation, but vary in the sub-type of channel upon which they act. Addition of mmol/l concentrations of extracellular $\mathrm{KCl}$ disrupts the potassium concentration gradient across the smooth muscle cell membrane, causing the membrane to become depolarised, which activates voltage-operated calcium channels (VOCCs) (43). In contrast, NA elicits smooth muscle contraction via alpha-1 adrenoceptor stimulation, which results in G-protein coupled activation of receptor-operated calcium channels (ROCCs) (44). The fact that the response to NA was not affected but the response to $\mathrm{KCl}$ was significantly reduced in vessels harvested from Tfm mice would suggest that the function of ROCCs is unaffected but the function of VOCCs is impaired.

These data also suggest that testosterone-mediated vasodilatation does not occur via the release of endothelial-derived products, nor via inhibition of VOCCs. If vasodilatation to testosterone did occur via the release of endothelial-derived vasodilators, then it would be expected that the response to testosterone would be impaired, as with ACh. Similarly, if testosterone-mediated vasodilatation occurred via inhibition of VOCCs, then it would be expected that the response to testosterone would be enhanced, since VOCC channel function is already reduced. Because the response to testosterone was not altered in vessels from Tfm mice, this would suggest that these vasodilatory mechanisms are not involved in the acute response to testosterone, which is in agreement with previous studies $(21,26,27)$. Clearly, further work is required to determine the underlying mechanism of testosterone-induced vasodilation.

However, whilst acute exposure to testosterone would appear not to modulate the release of endothelialderived vasodilators or the function of VOCCs (as discussed above), clearly the chronic hypotestosteronaemia/androgen receptor deficiency exhibited in this model does. Such marked alterations in vascular reactivity may well manifest as cardiovascular disease in later life. Impairment of endothelial function is well recognised to be a characteristic of the diseased 
coronary and systemic vessels common to CAD and peripheral vascular disease respectively, and a reduction in vasodilator capacity is proposed to be integral to the development of hypertension. Impaired calcium channel function is also likely to result in alterations in basal vascular tone, which may also be a contributory factor in the development of hypertension. Furthermore, elevated cholesterol levels may also result in the animals becoming prone to development of CAD. Recent studies from male patients with heart disease report a reduction in the circulating testosterone profile (reviewed in ref. 16), although it remains unknown whether this is a cause or effect of the disease state. The findings of the present study lend weight to the argument that the reduced levels of circulating testosterone may be a contributory factor to such conditions. Clearly, hypotestosteronaemia may indeed have serious consequences for the vasculature and may predispose to cardiovascular disease.

In summary, we have demonstrated that Tfm mice that lack a functional androgen receptor have significantly lower levels of circulating plasma testosterone and significantly elevated levels of serum cholesterol, compared with littermate control animals. These alterations in the circulating hormone profile are associated with a marked reduction in endothelial function, and impairment of the activity of VOCCs. This may have implications for the development of cardiovascular disease. The vasodilatory response to testosterone was unaffected, demonstrating no involvement of the androgen receptor, and implying the lack of involvement of endothelial-derived vasodilators or inhibition of VOCCs in this response. Because the Tfm mouse has a reduced level of circulating testosterone coupled with the lack of a functional androgen receptor, further experiments are required to determine which of these two characteristics are responsible for the observed alterations in endothelial and vascular function, and of the precise cellular mechanisms involved in producing these potentially deleterious vascular effects.

\section{Acknowledgements}

The authors wish to thank Mr Martin Loxley, Department of Clinical Chemistry, Royal Hallamshire Hospital, who organised the analysis of total cholesterol, progesterone and cortisol levels.

\section{References}

1 Charest NJ, Zhou ZX, Lubahn DB \& Olsen KL. A frameshift mutation destabilises androgen receptor messenger RNA in the Tfm mouse. Molecular Endocrinology 19915 573-581.

2 He WW, Kumar MV \& Tindall DJ. A frame-shift mutation in the androgen receptor gene causes complete androgen insensitivity in the testicular-feminised mouse. Nucleic Acids Research 1991 $192373-2378$.
3 Murphy L \& O'Shaughnessy PJ. Testicular steroidogenesis in the testicular feminised (Tfm) mouse: loss of 17 alpha-hydroxylase activity. Journal of Endocrinology $1991131443-449$.

4 Le Goascogne C, Sannanes N, Gouezou M, Baulieu EE \& Robel P. Suppressed expression of the cytochrome P45017 alpha protein in the testicular feminised (Tfm) mouse testes. Journal of Endocrinology $1993139127-130$.

5 Wingard DL, Suarez L \& Barrett-Connor E. The sex differential in mortality from all causes and ischaemic heart disease. American Journal of Epidemiology 1983117 165-172.

6 Jousilahti P, Vartiainen E, Tuomilehto J \& Puska P. Sex, age, cardiovascular risk factors, and coronary heart disease: a prospective follow-up study of 14786 middle-aged men and women in Finland. Circulation 199999 1165-1172.

7 Dickerman RD, McConathy WJ, Schaller F \& Zachariah NY. Cardiovascular complications and anabolic steroids. European Heart Journal 1996171912.

8 Sullivan ML, Martinez CM, Gennis P \& Gallagher EJ. The cardiac toxicity of anabolic steroids. Progress in Cardiovascular Diseases $1998411-15$.

9 English KM, Steeds R, Jones TH \& Channer KS. Testosterone and coronary heart disease: is there a link? Quarterly Journal of Medicine 199790 787-791.

10 Khaw KT \& Barrett-Connor E. Endogenous sex hormones, high density lipoprotein cholesterol, and other lipoprotein fractions in men. Arteriosclerosis and Thrombosis $199111489-494$.

11 Duell PB \& Bierman EL. The relationship between sex hormones and high-density lipoprotein cholesterol levels in healthy adult men. Archives of Internal Medicine 1990150 2317-2320.

12 Phillips GB, Pinkernell BH \& Jing TY. The association of hypotestosteronemia with coronary artery disease in men. Arteriosclerosis and Thrombosis $1994 \mathbf{1 4} 701-706$.

13 Hromadova M, Hacik T, Malatinsky E \& Riecansky I. Alterations of lipid metabolism in men with hypotestosteronemia. Hormone and Metabolic Research $199123392-394$.

14 Hromadova M, Hacik T, Malatinsky E, Sklovsky A, Cervenakov J \& Labady F. Lipid metabolism in young males with hypotestosteronaemia and oligospermia prior to, during, and after treatment. International Urology and Nephrology 199123 69-75.

15 English KM, Mandour O, Steeds RP, Diver MJ, Jones TH \& Channer KS. Men with coronary artery disease have lower levels of androgens than men with normal coronary angiograms. European Heart Journal 200021 890-894.

16 Alexandersen P, Haarbo J \& Christiansen C. The relationship of natural androgens to coronary heart disease in males: a review. Atherosclerosis $1996 \mathbf{1 2 5} 1-13$.

17 Wu SZ \& Weng XZ. Therapeutic effects of an androgenic preparation on myocardial ischaemia and cardiac function in 62 elderly male coronary heart disease patients. Chinese Medical Journal 1993106 415-418.

18 Jaffe MD. Effect of testosterone cypionate on post-exercise ST segment depression. British Heart Journal 197739 1217-1222.

19 English KM, Steeds RP, Jones TH, Diver MJ \& Channer KS. Lowdose transdermal testosterone therapy improves angina threshold in men with chronic stable angina: a randomised, double-blind, placebo-controlled study. Circulation 2000102 1906-1911.

20 Webb CM, McNeill JG, Hayward CS, de Zeigler D \& Collins P. Effects of testosterone on coronary vasomotor regulation in men with coronary heart disease. Circulation 1999100 1690-1696.

21 Yue P, Chatterjee K, Beale C, Poole-Wilson PA \& Collins P. Testosterone relaxes rabbit coronary arteries and aorta. Circulation $1995911154-1160$.

22 Chou TM, Sudhir K, Hutchison SJ, Ko E, Amidon TM, Collins P \& Chatterjee K. Testosterone induces dilation of canine coronary conductance and resistance arteries in vivo. Circulation 199694 2614-2619.

23 Murphy JG \& Khalil RA. Decreased [Ca(2+)](i) during inhibition of coronary smooth muscle contraction by 17 beta-estradiol, progesterone, and testosterone. Journal of Pharmacology and Experimental Therapeutics 1999291 44-52. 
24 English KM, Jones RD, Jones TH, Morice AH \& Channer KS. Testosterone acts as a coronary vasodilator by a calcium antagonistic action. Journal of Endocrinological Investigation 2002 25 455-458.

25 Jones RD, English KM, Pugh PJ, Morice AH, Jones TH \& Channer KS. Pulmonary vasodilatory action of testosterone: evidence of a calcium antagonistic action. Journal of Cardiovascular Pharmacology $200239814-823$.

26 Tep-areenan P. Kendall DA \& Randall MD. Testosterone-induced vasorelaxation in the rat mesenteric arterial bed is mediated predominantly via potassium channels. British Journal of Pharmacology $2002135735-740$

27 Deenadayalu VP, White RE, Stallone JN, Gao X \& Garcia AJ. Testosterone relaxes coronary arteries by opening the largeconductance, calcium-activated potassium channel. American Journal of Physiology. Heart and Circulatory Physiology 2001281 H1720-H1727.

28 Rogers TK, Stewart AG \& Morice AH. Effect of chronic hypoxia on rat pulmonary resistance vessels - vasodilatation by atrial natriuretic peptide. Clinical Science 199283 723-729.

29 Coats P \& Hillier C. Determination of an optimal axial-length tension for the study of isolated resistance arteries on a pressure myograph. Experimental Physiology 199984 1085-1094.

30 English KM, Jones RD, Jones TH, Morice AH \& Channer KS. Ageing reduces the responsiveness of coronary arteries from male Wistar rats to the vasodilatory action of testosterone. Clinical Science $20009977-82$.

31 Ding AQ \& Stallone JN. Testosterone-induced relaxation of rat aorta is androgen structure specific and involves $\mathrm{K}^{+}$channel activation. Journal of Applied Physiology $2001912742-2750$.

32 Benten WP, Lieberherr M, Sekeris CE \& Wunderlich F. Testosterone induces $\mathrm{Ca}^{2+}$ influx via non-genomic surface receptors in activated T cells. FEBS Letters $1997 \mathbf{4 0 7} 211-214$.

33 Benten WP, Lieberherr M. Stamm O, Wrehlke C, Guo Z \& Wunderlich F. Testosterone signaling through internalizable surface receptors in androgen receptor-free macrophages. Molecular Biology of the Cell $1999103113-3123$.

34 Gorczynska E \& Handelsman DJ. Androgens rapidly increase the cytosolic calcium concentration in Sertoli cells. Endocrinology $19951362052-2059$.
35 Jones RD, Ruban L, English KM, Pugh PJ, Channer KS \& Jones TH. Identification of a testosterone binding site in the smooth muscle cell membrane. Endocrine Abstracts 20011 P186.

36 English KM, Jones RD, Morice AH, Channer KS \& Jones TH. Testosterone is a potent arterial vasodilator in testicular feminised mice with a non-functional androgen receptor. 82nd American Endocrine Society Meeting 2000 P1430.

37 English KM, Jones RD, Jones TH, Morice AH \& Channer KS Gender differences in the vasomotor effects of different steroid hormones in rat pulmonary and coronary arteries. Hormone and Metabolic Research 200133 645-652.

38 Lee DY, Chai YG, Lee EB, Kim KW, Nah SY, Oh TH \& Rhim H. 17 Beta-estradiol inhibits high-voltage-activated calcium channel currents in rat sensory neurons via a non-genomic mechanism. Life Sciences $2002702047-2059$.

39 Burger K, Fahrenholz F \& Gimpl G. Non-genomic effects of progesterone on the signalling function of $G$ protein-coupled receptors. FEBS Letters $1999 \mathbf{4 6 4} 25-29$.

40 Buttgereit F, Brand MD \& Burmester GR. Equivalent doses and relative drug potencies for non-genomic glucocorticoid effects: a novel glucocorticoid hierarchy. Biochemical Pharmacology 1999 $58363-368$.

41 Keightley MC. Steroid receptor isoforms: exception or rule? Molecular and Cellular Endocrinology $19981371-5$.

42 Stallone JN, Salisbury RL \& Fulton CT. Androgen-receptor defect abolishes sex differences in nitric oxide and reactivity to vasopressin in rat aorta. Journal of Applied Physiology 200191 $2602-2610$

43 Nelson MT \& Quayle JM. Physiological roles and properties of potassium channels in arterial smooth muscle. American Journal of Physiology 1995268 C799-C822.

44 Weber LP, Chow WL, Moshenko J, Belsher S \& MacLeod KM. Pharmacological investigation of signalling mechanisms contributing to phasic and tonic components of the contractile response of rat arteries to noradrenaline. Canadian Journal of Physiology and Pharmacology 199573 594-601.

Received 4 July 2002

Accepted 25 September 2002 